DOI: $10.37317 /$ pbss-2019-0002

Wioletta M. Dynkowska

Plant Biochemistry and Physiology Department, Plant Breeding and Acclimatization Institute - National Research Institute,Radzików, 05-870 Błonie, Poland; *Corresponding author e-mail: w.dynkowska@ihar.edu.pl

\title{
RYE (SECALE CEREALE L.) PHENOLIC COMPOUNDS AS HEALTH-RELATED FACTORS
}

\begin{abstract}
The diversity of phenolic compounds found in rye grain makes this cereal the valuable source of these substances in everyday food. Simple phenolic compounds, as well as their metabolites, show a pro-health effect. Phenolic acids and ferulic acid dehydrodimers are included in the group of cereal antioxidants. The antioxidant activity of phenolic compounds is an essential factor in the prevention of cancer and cardiovascular diseases.
\end{abstract}

Keywords: Rye (Secale cereale L), phenolic compounds, antioxidant activity, health potential, rye bread

\section{INTRODUCTION}

Rye (Secale cereale L.) is the second most crucial bread cereal in Europe successively after wheat. Lower soil and climatic requirements compared to wheat make the rye grown on lands of a lower bonitation class, as well as in countries with a more severe climate. It is a principal reason to cultivate this cereal in Eastern and Northern Europe and Canada. The leading producer in Europe is Germany (3.8 mln tons $\times$ year $^{-1}$; 662 thousand ha) and Poland (2.6 mln tons $\times$ year $^{-1} ; 28.7 \mathrm{~kg} \times$ ha $^{-1}$, avg 915 thousand ha) next to Russia as a country with the largest cultivation area of this cereal $\left(1.77\right.$ tons $\left.\times \mathrm{ha}^{-1}\right)$ but with a low yield of its production (avg 1.5 million ha). Since 2013, a slight de-

Communicated by Grzegorz Żurek 
crease in the area of rye cultivation of leading producers has been noticed; nevertheless, they constitute about 3.78 million ha (FAOSTAT, 2018).

In Poland, rye is used mainly for consumption ( $40 \%$ of national resources) and industrial purposes for the spirit and feed production (44\%) with only $10 \%$ for sowing (Statistical Yearbook, 2017; Cacak-Pietrzak, 2016). Nowadays, rye varieties not suitable for consumption and feed industries can be successfully used for the silage productions to be a substrate in the biogas production as an alternative source of energy because of the excellent content and composition of saccharides.

A significant contribution of rye intended for consumption was historically associated with low soil and agrotechnical requirements and relatively high resistance to biotic and abiotic stresses. Currently, it is due to the high concentration of dietary fiber in the grain (15-21\% of dry matter) (Ragaee et al. 2001; Hansen et al. 2003), as well as the increase in nutritional awareness of consumers. Over the last 50 years, there has been a significant decrease in the consumption of dark rye bread, from about $50 \%$ to $2 \%$ of the total consumption of bread. The reason can be seen in the technology of preparing rye dough, more complicated than in the case of selecting wheat as the primary raw material, but also organoleptic features seemingly inferior to the consumer, for example, smaller volume, darker crumb color, more acidic taste, and sharper aroma.

Rye bread is a valuable source of phenolic compounds. Their healthpromoting properties are based on antioxidant activity. Increased consumption of rye products reduces the risk of developing civilization diseases, primarily cardiovascular diseases, as well as the incidence of certain types of cancer, e.g., colorectal or prostate cancer. Using rye flour as a component of flour mixtures for baking mixed-wheat-rye bread causes the increasing availability of phenolic compounds in the daily diet in comparison with the bread produced only from wheat flour.

The aim of this review is presenting rye phenolic compounds, their structure, properties and positive effects on human health.

\section{PHENOLIC COMPOUNDS IN RYE GRAIN}

Phenolic substances are a group of aromatic compounds with significant structural heterogeneity resulting from the number of benzene rings as well as the quality and quantity of groups attached to the aromatic ring. Phenolic acids are synthesized in shikimic acid pathway occurring in plastids (Maeda and Dudareva, 2012; Tzin and Galili, 2010; Weaver and Herrmann, 1997), where phenylalanine, tyrosine $\mathrm{i}$ tryptophan are the substrates in phenolic compounds synthesis, whereas flavonoids are produced in polyketide pathway (Cheynier et al. 2013; Quideau et al. 2011). Phenolic compounds are divided into several groups. Their heterogeneity is a result of the amount and distribution of aromatic rings and the amount, quality, and location of substitution of functional groups such as hydroxyl, methyl, or methoxy group.

The distribution of phenolic compounds in rye grain is not regular. These substances are main components of the cell-walls. The most abundant phenolic 
compounds occur in the outer layers of rye kernel (Glitsø and Bach Knudsen, 1999) and with the increasing both thickness of the cell-walls and degree of lignification, the content of phenolics in grain increases (Bunzel et al. 2001; Izydorczyk and Biliaderis, 1995; Kroon and Williamson, 1999; Saulnier and Thibault, 1999).

\section{Phenolic acids}

Phenolic acids are the most abundant form of phenolic compounds found in rye kernels (Fig.1). The structure of molecules of phenolic acids allows to divide them into two basic groups. The first group includes $p$-hydroxybenzoic acid and its derivatives, such as vanillic and syringic acid. The second group is $p$-coumaric acid and its derivatives, mainly ferulic and caffeic acid.<smiles>O=C(O)c1ccc(O)cc1</smiles><smiles>COc1cc(C(=O)O)ccc1O</smiles><smiles>COc1cc(C(=O)O)cc(OC)c1O</smiles><smiles>O=C(O)C=Cc1ccc(O)cc1</smiles><smiles>O=C(O)C=Cc1ccc(O)c(O)c1</smiles><smiles>COc1cc(/C=C/C(=O)O)ccc1O</smiles><smiles>COc1cc(C=CC(=O)O)cc(OC)c1O</smiles>

g)

Fig. 1. The structure of phenolic acid in rye grain: a) p-hydroxybenzoic acid, b) vanillic acid, c) syringic acid, d) p-coumaric acid, e) caffeic acid, f) ferulic acid, g) sinapic acid.

Ferulic acid is the dominant compound of this group $\left(980 \mu \mathrm{g} \times \mathrm{g}^{-1} \mathrm{dm}\right.$ of rye grain). Sinapic acid and $p$-coumaric acid constitute $0.02 \%$ and $0.005 \% \mathrm{dm}$ of rye grain, respectively, while the level of other acids (caffeic, vanillic, syringic, and $p$-hydroxybenzoic) is negligible (Dynkowska et al. 2015; Rothwell et al. 2016).

All $p$-hydroxycinnamic acids occur in two isomeric forms, the predominating trans- form (85-90\% of all acids) and cis-. The conversion of the trans- form to the cis- form in vivo conditions takes place with the presence of the specific 
cis-trans isomerases. In contrast, in vitro this process is caused by ultraviolet radiation (Geissman and Neukom, 1973).

In rye grain, phenolic acids occur mainly in bound form, being as cell-wall components. About $85 \%$ of these compounds, in particular, ferulic acid, are covalently linked with arabinoxylans and lignin (Acosta-Estrada et al., 2014; Shahidi and Yeo, 2016). About $12 \%$ of the total content of phenolic acids usually are conjugated with both sugars as glycosides or with sterols as their esters (Bondia-Pons et al., 2009). Free phenolic acids represent less than $3 \%$ of the total phenol content.

\section{Ferulic acid dehydrodimers}<smiles>COc1cc(CC(Oc2ccc(CCC(=O)O)cc2OC)C(O)O)ccc1O</smiles>

a)<smiles>COc1cc(C[C@@H](C(=O)O)c2cc(CCC(=O)O)cc(OC)c2O)ccc1O</smiles>

b)

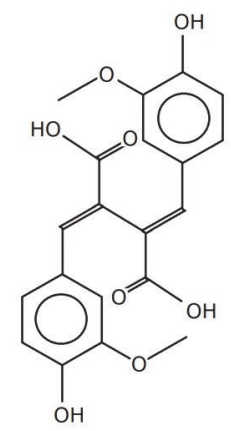<smiles>COc1cc(C2Oc3c(OC)cc(CCC(O)O)cc3C2C(O)O)ccc1O</smiles>

c)<smiles>COc1cc(CCC(O)O)cc(-c2cc(CCC(O)O)cc(OC)c2O)c1O</smiles><smiles>COc1cc(C2c3cc(O)c(OC)cc3C=C(C(=O)O)C2C(O)O)ccc1O</smiles>

f)

Fig. 2 The structure of ferulic acid dehydrodimers: a) 8-O-4', b) 8-5' linear form, c) 8-5' benzofuran form, d) $5-5$ ', e) $8-8$ ' linear form, f) $8-8$ ' aryltetraline form. 
Ferulic acid dehydrodimers (DiFA) are formed as a result of the arabinoxylan cross-linking process (Fig.2). The oxidative mechanism of cross-linking is based on catalytic dehydrogenation of a hydroxyl group at the $\mathrm{C}-4$ position of the aromatic ring; thus, highly reactive isomeric phenoxyl radicals are formed. The activity center with the unpaired electron is located at the C-5 location in the aromatic ring or C-8 position of the side propenoic chain. Generated radicals can combine each other to form $\mathrm{C}-\mathrm{C}$ bonds resulted in the isomeric structures of ferulic acid dehydrodimers. Steric hindrances cause the formation of only a few dehydrodimeric isomers (Ralph et al. 1994). A more significant role of the aromatic ring than the propenoid group has been proved as a factor influenced by the cross-linking process (Vinkx et al. 1991). The catalyst agent is the oxidation-reduction system, consisting of hydrogen peroxide and peroxidase (Ralph et al. 1994) or fungal laccase with the cell-wall peroxidase (Figueroa-Espinoza and Rouau, 1998). In contrast, the factor limiting cross-linking of arabinoxylans is the concentration of hydrogen peroxide, while ferulic and vanillic acids are cross-linking inhibitors (Moore et al. 1990) similarly as ascorbic acid and cysteine, which reduce the amount of hydrogen peroxide through competitive reactions (Vinkx et al. 1991).

Among the dimers, 8-O-4'-DiFA dehydrodimer occurs in the highest concentration, and its content in rye grain is $125-150 \mu \mathrm{g} \times \mathrm{g}^{-1} \mathrm{dm}$, which is $0.012-0.015 \% \mathrm{dm}$. The $8,5^{\prime}$-DiFA occurs in two spatial configurations, as linear and benzofuran form and their content in rye grain is estimated on 30 $-40 \mu \mathrm{g} \times \mathrm{g}^{-1} \mathrm{dm}$ and $70-90 \mu \mathrm{g} \cdot \times \mathrm{g}^{-1} \mathrm{dm}$, respectively. The 5,5'-DiFA, formerly considered as the main arabinoxylan cross-linking factor, is present in similar concentration ( $40-60 \mu \mathrm{g} \times \mathrm{g}^{-1} \mathrm{dm}$ ). In contrast, two spatial configurations of $8,8^{\prime}$-DiFA: linear and aryltetralin, are found in trace amounts compared to the main representatives of this group of compounds (Andreasen et al. 2000).

\section{Other phenolic compounds}

Flavonoids are a group of plant phenolic compounds with huge structural diversity (Fig.3). There are polycyclic aromatic compounds formed from aromatic amino acids: phenylalanine and tyrosine and malonyl anion (Gulçin, 2012). The basic flavonoid structure is flavane $\left(\mathrm{C}_{15} \mathrm{H}_{14} \mathrm{O}\right)$, a tricyclic aromatic compound $\left(\mathrm{C}_{6}-\mathrm{C}_{3}-\mathrm{C}_{6}\right)$. The presence of a double bond and the amount and location of the carbonyl and hydroxyl groups in the flavan skeleton is a primary factor to their classification (Cheynier et al., 2013; Gulçin, 2012; Heim et al., 2002; Rice-Evans et al., 1997; Shahidi and Yeo, 2016).

So far, there is a little knowledge of rye flavonoids. In 1970s cyanidin and peonidin were found as glycosides and rutosides (Dedio et al. 1972), while the latest works indicate the presence of also delphinidin and their content was determined as a total of $30 \mathrm{mg} \times \mathrm{kg}^{-1} \mathrm{dm}$ of rye grain. Difficulties in determining of flavonoids are a result not only in a large diversity and complexity of their spatial structures and the fact that these substances occur as aglycones (nonsugars parts of glycosides) but also from their trace content in the grain. Typically quantitative determination of flavonoids was based on a colorimetric analysis. The results were expressed in catechin equivalents (CE) and depended on the method of extraction of flavonoids. The 
obtained result depended on the method of extraction of flavonoids. It ranged from $80 \mu \mathrm{g} \mathrm{CE} \times \mathrm{g}^{-1}$ d.m. for phosphate-buffered saline (PBS) buffer up to about $400 \mu \mathrm{g}$ $\mathrm{CE} \times \mathrm{g}^{-1} \mathrm{~d}$.m. for methanol solution (Michalska et al., 2007a; Michalska et al., 2007b; Zieliński et al., 2007). The use ultra-high-pressure liquid chromatography equipped with a mass spectrometer allow for more precise determination of the structural characteristics and diversity of flavonoids, whereas in the case of colorimetric determination of flavonoids the presence of other compounds in extraction medium cause possible interference so the quantitative data may strongly overestimate their amount (Pihlava et al. 2018; Pihlava et al. 2015).<smiles>Oc1cc(O)c2cc(O)c(-c3cc(O)c(O)c(O)c3)[o+]c2c1</smiles>

a)<smiles></smiles>

c)<smiles></smiles>

b)<smiles>Oc1cc(O)c2cc(O)c(-c3ccc(O)c(O)c3)[o+]c2c1</smiles>

d)

Fig. 3. The structure of rye flavonoids: a) cyanidin, b) peonidine, c) luteolin, d) delphinidine.

5-n-Alkylresorcinols (Fig.4) are a group of nonisoprenoids phenolic lipids, alkyl derivatives of resorcinol. Their content in rye grain varies from 268 to $1444 \mu \mathrm{g} \times \mathrm{g}^{-1}$ d.m. (Poutanen and Åman, 2014). The hydrocarbon side chain substituted at the C-5 position of the aromatic ring is characterized by an odd number of carbon atoms (13-27 carbon atoms), and mostly no double bonds occur in it (Kulawinek et al. 2008). A small amount of 5-n-alkylresorcinols (up to $10 \%$ of the total contents) with the unsaturated side chain usually contains one (5-n-alkenylresorcinols) or two (5-n-alkadieneresorcinols) cis- double bonds, located at the center of the chain (Suzuki et al. 1997), as well as side substituents like the keto or hydroxyl groups (Nyström et al. 2008; Suzuki et al. 1999). These compounds are cumulated in the outer layers of rye kernel and considered as biomarkers in rye whole-grain products consumption (Chen et al. 2004). 


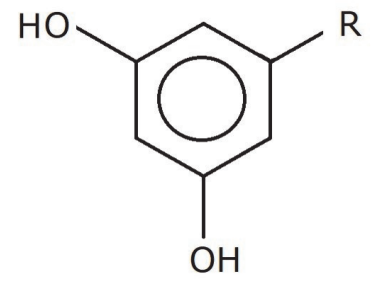

Fig. 4. The structure of rye 5-n-alkyloresorcinols. R - saturated (5-n-alkylresorcinols) or unsaturated (5-n-alkenylresorcinols, 5-n-alkadieneresorcinols) hydrocarbon chain.

Tocopherols and tocotrienols (Fig.5) present in rye grain in the amount $32-39 \mu \mathrm{g} \times \mathrm{g}^{-1} \mathrm{~d}$.m. are the valuable source of the vitamin $\mathrm{E}$ (Poutanen and Åman, 2014), synthesized only in plants (Kamal-Eldin and Appelqvist, 1996). These compounds are derivatives of chroman, and their division is determined by the saturation of the hydrocarbon chain substituted in the C-2 position. Four kinds of these components were found in rye grain: $\alpha$-tocopherols, $\alpha$-tocotrienols, $\beta$-tocopherols, and $\beta$-tocotrienols (Bushuk, 2001; Piironen et al., 1986).<smiles>Cc1c(C)c2c(c(C)c1O)CC[C@@](C)(CCCC(C)(C)CCCC(C)(C)CCCC(C)C)O2</smiles>

a)<smiles>Cc1cc(O)c(C)c2c1O[C@](C)(CCCC(C)(C)CCCC(C)(C)CCCC(C)C)CC2</smiles>

c)<smiles>CC(C)=CCC/C(C)=C/CC/C(C)=C/CC[C@]1(C)CCc2c(C)c(O)c(C)c(C)c2O1</smiles>

b)<smiles>CC(C)=CCC/C(C)=C/CC/C(C)=C/CC[C@]1(C)CCc2c(C)c(O)cc(C)c2O1</smiles>

d)

Fig. 5. The structure of rye grain tocorefols and tocotrienols: a) $\alpha$-tocoferol, b) $\alpha$-tocotrienol,c) $\beta$-tocoferol, d) $\beta$-tocotrienol.

Benzoxazinoids (Fig.6) are a group of indole derivatives occurring in rye grains in trace amounts $\left(64-161 \mu \mathrm{g} \times \mathrm{g}^{-1} \mathrm{dm}\right)$. These groups of bioactive compounds present in rye grain has been isolated and described in recent year due to availability of advanced research techniques, primarily the liquid chromatography combined with photodiode array detector and mass spectrometer (Katina et al., 2007; Pihlava et al., 2018). However the first mention of the presence benzoxazinoids in rye grain appeared in the 1950s (Virtanen and Hietala, 1955). 
<smiles>O=C1C(O)Oc2ccccc2N1O</smiles><smiles>O=C1Nc2ccccc2OC1O</smiles><smiles>O=c1[nH]c2ccccc2o1</smiles><smiles>COc1ccc2c(c1)OC(O)C(=O)N2O</smiles><smiles>COc1ccc2c(c1)OC(O)C(=O)N2</smiles><smiles>COc1ccc2[nH]c(=O)oc2c1</smiles>

Fig. 6. The structure of molecules of particular groups of rye benzoxazinoids: a) hydroxamic acids, b) laktams, c) benzoxazolinons

Benzoxazinoids were divided into three classes of compounds: hydroxamic acids, lactams, and benzoxazolinones. These compounds predominantly act as aglycones, mainly with glucose (Poutanen and Åman, 2014).<smiles>COc1cc(CC(CO)C(CO)Cc2ccc(O)c(O)c2)ccc1O</smiles><smiles>COc1cc(CC2CCC(=O)C2Cc2ccc(O)c(O)c2)ccc1O</smiles>

b)<smiles>COc1ccc(C2CCC3C(c4cc(O)c(O)c(O)c4)COC23)cc1O</smiles><smiles>COc1cc(CC2CCC(=O)C2C(O)c2ccc(O)c(O)c2)ccc1O</smiles><smiles>COc1ccc(C2CCC(c3ccc(O)c(O)c3)C2CO)cc1O</smiles>

d)<smiles>COc1cc(C2CCC3C(c4cc(O)c(O)c(O)c4)OCC23)cc(O)c1O</smiles>

h)

Fig. 7. Rye grain lignans: a) secoisolariciresinol, b) matairesinol, c) pinoresinol, d) lariciresinol, e) isolariciresinol, f) medioresinol, g) 7-hydroxymatairesinol, h) syringaresinol

Lignans (Fig.7) are a group of phenylpropanoid-derived compounds present in the outer layers of rye kernels in the amount of 25-67 $\mu \mathrm{g} \times \mathrm{g}^{-1} \mathrm{dm}$. The most important compounds present in rye grain are secoisolariciresinol, matairesinol, pinoresinol, lariciresinol, isolariciresinol, medioresinol, 7-h hydroxymatairesinol, and syringaresinol. (Bondia-Pons et al., 2009; Pihlava et al., 2015). Lignans are classified as phytoestrogens due to the structural similarity of molecules. In the human body under the influence of bacterial microflora, lignans are metabolized 
to enterolactone and enterodiol, compounds showing pro-healthy activity (Bondia-Pons et al. 2009).

Tannins are a wide range of oligomeric and polymeric compounds, which, due to the type of monomer building them, have been divided into two groups: hydrolyzable and condensed. The building block of hydrolyzable tannins is polymerized gallic acid or its dimer, ellagic acid, esterified with glucose, thereby distinguishing gallotannins and ellagitannins. In contrast, condensed tannins referred to as proanthocyanidins, are oligomeric and polymeric polycyclic aromatic compounds with conjugative rings in which flavonoids, in particular, cyanidin, are building units. Molecular masses of hydrolyzable tannins are in the range of 500-2800 g $\times \mathrm{mol}^{-1}$, whereas molecular masses of proanthocyanidins are much higher $(2000$ $\left.-4000 \mathrm{~g} \times \mathrm{mol}^{-1}\right)($ Naczk and Shahidi, 2004).

Lignin, a hydrophobic cell-wall substituent with an irregular structure, is composed of $p$-hydroxyphenyl, guaiacyl, and syringynyl units (Hatfield et al. 2017). Its hydrophobicity is a result of the existence of many aromatic groups in the structure. The existence of ester bonds linking arabinoxylans and lignin by dehydrodiferulic bridges formation and also in minor scale dehydrodimers formed by the $p$-coumaric residues have been demonstrated (Iiyama et al. 1994; Lam et al. 2001; Wong et al. 1988). The presence of linkages between the arabinoxylans and lignin determines the water's insolubility of arabinoxylanlignin complex. The lignification is the last step of secondary cell-wall biosynthesis, finally giving the functionally matured cell wall (Meents et al. 2018).

\section{ANTIOXIDANT POTENTIAL OF PHENOLIC COMPOUNDS}

The antioxidant potential of the sample is defined as its ability to eliminate reactive oxygen species (ROS) by antioxidants molecules, whereas the biological function of antioxidants is to protect against the destructive effects of ROS in the organism. This protection can be based on various mechanisms of action. One of the fundamental mechanism is the direct scavenging of free radicals by the redox reaction by providing a single electron or an hydrogen atom (BrandWilliams et al. 1995; Huang et al. 2005; Prior et al. 2005; Re et al. 1999; Sroka and Cisowski, 2003) as well as indirect actions preventing their production (Slavin, 2000). These compounds include, by chelation, metal ions, such as $\mathrm{Fe}^{2+}$ or $\mathrm{Cu}^{2+}$ responsible for the formation of free radicals in a Fenton's reaction (Heim et al. 2002). Furthermore are responsible for blocking the action of enzymes catalyzing ROS synthesis (Moon and Shibamoto, 2009; Ou and Kwok, 2004; Pisoschi and Pop, 2015), and also the support of peroxidases and superoxide dismutases (SOD) which are the body's defenses (Gulçin, 2012; RiceEvans et al., 1997).

The high antioxidant activity of phenolic compounds is a result of their molecular structure. The coupling of the free electron pairs of the oxygen atom of the hydroxyl group and aromatic ring with strongly negative, delocalized charge, as well as the electron pair of the carboxyl group and multiple valence bonds result in stabilization of phenoxy radical by resonance. In determining the antioxidant activity of chemical compounds, the position and degree of hydroxylation is of great 
importance as well as the arrangement of aromatic rings (Heim et al., 2002; Rice-Evans et al., 1997; Rice-Evans et al., 1996; Williams et al., 2004). It was also found that the molecules with a higher number of aromatic rings show stronger antioxidant properties than monocyclic structures (Gulçin, 2012; RiceEvans et al., 1996; Rice-Evans et al., 1997). Hydroxycinnamic acid derivatives are stronger antioxidants than hydroxybenzoic acid derivatives (Natella et al., 1999; Nimse and Pal, 2015; Rice-Evans et al., 1996). The chemical nature of the hydroxyl group and its position relative to other substituents present in aromatic ring (e.g., additional hydroxyl or methoxyl groups) also affect the antioxidant properties of this group of compounds (Gülçin, 2012; Sroka and Cisowski, 2003).

Rye grain as biological material contains a lot of substances being classified as antioxidants, and is not possible to give the value of antioxidant potential to each of them individually. Due to the different mechanisms of reactions running parallel and the dependence of the extraction medium as well as the acidity of aqueous solutions, there is no one universal method to measure the antioxidant potential of the biological sample. Two main mechanisms of antioxidant reactions consisting of the transfer of a hydrogen atom (HAT) or single electron transfer (SET) differ in both kinetic of reaction and the use of appropriate substrates depending on the reaction environment and oxidative factor (Prior et al., 2005). At least three different tests measuring the antioxidant potential of the sample show a more full spectrum of this characteristic.

The antioxidant potential is expressed using a reference substance, e.g., ferulic or gallic acid or catechin and ascorbic acid. This parameter is most often given as the Trolox equivalent, a water-soluble synthetic derivative of vitamin E. The unit of measurement is $\mu \mathrm{mol} \mathrm{TE} \times 100 \mathrm{~g}^{-1}$ of the probe, for samples with a higher potential the $\mu \mathrm{mol} \mathrm{TE} \times \mathrm{g}^{-1}$ are used.

\section{HEALTH EFFECTS OF PHENOLIC COMPOUNDS}

Long-term studies in vivo and in vitro in humans and animals provided the evidence for health-promoting effects of phenolic compounds in the case of cardiovascular diseases, type 2 diabetes, and also degenerative and cancer diseases (Fazary and Ju, 2007; Mathew and Abraham, 2004; Ou and Kwok, 2004; Shahidi and Yeo, 2016). The antioxidative action of steryl ferulate was found in relation to liposomes (Bondia-Pons et al. 2009) by neutralization of free radicals and chelation of metal ion $\left(\mathrm{Fe}^{2+}\right.$ and $\left.\mathrm{Cu}^{2+}\right)$ which are responsible to their formation (Budryn and Nebesny, 2006). Chelation effect was also observed in the case of caffeic acid (Kołodziejczyk-Czepas et al. 2015). Ferulic acid, by inhibiting certain enzymes, e.g., hydroxymethyl glutaryl-coenzyme-A-reductase in the liver or thromboxane-A2-synthetase, significantly reduces cholesterol synthesis and prevents the occurrence of thrombosis (Ou and Kwok, 2004). The inhibitory effect of ferulic acid is revealed by blocking bacterial enzymes, e.g., the inhibition of the activity of bacterial arylamine-N-acetyltransferase, which results in bactericidal and anti-inflammatory properties of ferulic acid (ibid.). Also, the catalytic activity of ferulic acid is showed in increasing the activity of detoxifying 
enzymes: glutathione S-transferase and quinone reductase in the liver and the intestine, in turn, the processes of intestinal cell carcinogenesis caused by the action of free radicals are inhibited (ibid.).

In the large intestine, in the presence of bacterial intracellular O-demethylase, the demethylation of ferulic acid occurs, and this process leads to the formation of caffeic acid with stronger antioxidant activity than ferulic acid due to presence additional hydroxyl group attached to the aromatic ring (Micard et al., 2002). The strong antioxidant activity of caffeic acid has been confirmed by the epidemiological studies showing a relationship between regular coffee consumption and a decrease in the incidence of Parkinson's disease, type 2 diabetes, and cancers of the excretory system and large intestine (Budryn and Nebesny, 2006). The protective effect of caffeic acid has been also found in studies on lipid oxidation (Masuda et al. 2008). In contrast, ferulic acid derivatives are thermally unstable, and the products of its decomposition may have a pro-oxidant effect (Kołodziejczyk-Czepas et al., 2015).

Similar pro-healthy effects were found for flavonoids. Epidemiological studies have shown the correlation between the intake of flavonoids and the reduced risk of cardiovascular heart disease, gastrointestinal cancer, and neurodegenerative diseases, and the protective effect can be attributed to the antioxidative activity of these compounds (Viskupičová et al. 2008). Moreover, the antimicrobial, antiviral, anti-cancer, anti-inflammatory, anti-allergic, and vasodilatory actions of flavonoids were found (ibid.). Flavonoids have also been shown to inhibit the lipid oxidation and blood cell platelets aggregation, regulate the permeability and sensitivity of blood capillary vessels as well as affect the enzymatic systems, including phospholipase A2, cyclooxygenase and lipoxygenase and number of ATP-binding proteins (ibid.).

Lignans, in particular, their metabolites - enterodiol and enterolactone, can play a preventive role in the breast, prostate, and liver cancers development. Inhibitory effect of lignans and their metabolites is assigned to suppressing proliferation and migration of prostate cancer cells partly by inhibition of insulinlike growth factor-1 receptor signaling, which is necessary for prostate cancer cell growth and progression. (Andersson et al. 2014). The anti-inflammatory effect of lignans was also found. Pinoresinol was shown to have the most potent force in vitro by blocking the NF-kB signaling pathway, possibly concerning its molecular structure and its conjugation efficacy in intestinal cells (During et al., 2012).

\section{METABOLISM IN THE HUMAN DIGESTIVE TRACK}

Studies on rats showed that the digestibility of phenolic compounds depends on the form in which they are present in food, and thus how they are transferred into the organism (Andreasen et al. 2001b). Free ferulic acid can be absorbed directly by the small epithelial cell; however, there is only $10 \%$ of the total amount of this acid assimilated in food (Shahidi and Yeo, 2016). Absorption models in situ or ex vivo indicate that ferulic acid is acquired from the small intestine (jejunum and ileum) and stomach (Zhao and Moghadasian, 2008). The 
researches provided by Williamson revealed that the absorption of flavonoids in the small intestine is diverse, which was attributed to the different selectivity of enterocytes in various organisms as well as the diversified structure of these compounds (Williamson et al. 2000).

Due to the presence of the bacterial flora, a large intestine is a primary place of metabolism of phenolic compounds in the human body. A significant part of ferulic acid is present as a cell-wall component; thus, before the absorption, it must be enzymatically released from the polysaccharide matrix by specific hydroxycinnamic esterases (Andreasen et al. 2001a; Ou and Kwok, 2004) produced by human bacterial flora. Ferulic acid dehydrodimers are also released. (Kroon et al. 1999; Biely et al. 2016). The metabolism of chemically unstable flavonoid aglycones, which were not absorbed in the small intestine, is performed in the large intestine (Selma et al. 2009). The enzymatic action of bacterial flora determines a series of biochemical alterations, including the degradation of aromatic rings of flavones. Resulting metabolites retain their biological activity and can be absorbed into the organism (Williamson et al. 2000).

The studies in rats have proven the presence of many ferulic acid metabolites, including its conjugates with the sugars, amino acids, and even with inorganic acid ions. The formation of conjugates of ferulic acid with glucuronic acid or sulphate (VI) ion appears to be the main metabolical pathway of ferulic acid, and this process takes place in the liver. It is catalyzed by the suplhotransferase (EC 2.8.2.1) and glucuronosyltransferase UDP (EC 2.4.1.17). Also, ferulic conjugates are formed in the membrane mucous intestine and kidneys. This process seems to be dependent on the amount of ferulic acid in food (Zhao and Moghadasian, 2008; Ou and Kwok, 2004).

The metabolism of unabsorbed hydroxycinnamic acids (in particular ferulic, $p$-coumaric and caffeic) is carried out by enzymes produced by Lactobacillus brevis strains present in human flora. In the large intestine, $p$-hydroxycinnamic acids are decarboxylated, and the final products are $p$-vinyl guaiacol, $p$-vinyl phenol and $p$-vinyl catechol, respectively, that diffuse through the wall of the large intestine to the plasma (Chesson et al. 1999; Curiel et al. 2010).

Both ferulic acid and its metabolites are excreted mainly in the urine. The rate of excretion is species-dependent; in rats, the plateau is reached 1.5 hours after ingestion, whereas in humans, this process is much slower, and the plateau is reached between 7 and 9 hours after ingestion (Mancuso and Santangelo, 2014).

\section{IMPACT ON THE BREAD QUALITY}

The technological effects of sourdough on the flavor, texture, shelf-life, and nutritional quality of bread are dependent on bioconversion of flour components at the dough stage (Gänzle, 2014). Bioconversion of phenolic acids is dependent on the lactic acid bacteria strain (Rodriguez et al., 2009). So far, phenolic acids in plants have been considered as anti-nutritional factors that impart a bitter taste although they are exerted beneficial health effects as antioxidants (Ragaee et al., 2006; Dykes and Rooney, 2007; Katina et al., 2007; Poutanen et al., 
2009). In recent years it has been proven that phenolic compounds, along with amino acids, are one of the groups of taste and aroma precursors during the bread-making (Heiniö et al. 2003; Heiniö et al. 2008; Katina et al. 2006; Rodrigues et al. 2009). Dimberg et al. (1996) indicate the role of phenolic acids as well as their reduced form, i.e., aldehydes (vanillin and $p$-hydroxybenzaldehyde) as taste and aroma components. Also, phenolic acids as antioxidants can affect the rate of lipid oxidation (Moltenberg et al. 1996), followed by a generation of their derivatives with unpleasant for consumers taste and aroma, particularly rancid and bitter. In addition to phenolic acids and mentioned earlier aldehydes, other phenolic derivatives affect the aroma and taste of bread, particularly hydroxycinnamic acids vinyl- and ethyl- derivatives. Their presence is depended on the interaction of enzymes produced by both yeast and lactic acid bacteria. As a result of the action of feruloyl or $p$-coumaroyl decarboxylase, decarboxylation of hydroxybenzoic and hydroxycinnamic acids are to the corresponding phenol- or vinyl- derivatives (Rodriguez et al., 2009). Furthermore, the action of the vinyl phenol/guaiacol reductase on hydroxycinnamic acids vinyl derivatives results in the hydrogenation of the $\mathrm{C}-\mathrm{C}$ double bond and formation of ethyl - derivatives (van Beek and Priest, 2000).

\section{CONCLUSIONS}

Technological progress with the result in negative changes both in personal motoric development and daily diet and constantly increasing environmental pollution cause a steady rise in the incidence of cancer, cardiovascular diseases, type 2 diabetes and obesity. Therefore it is extremely important to propagate the information about the health-promoting properties of antioxidant substances naturally found in food. The diversity of phenolic compounds present in the rye grain in combination with the unique properties of rye arabinoxylans make this cereal valuable component of the daily diet. The use of the modern analytical techniques allowed for a more accurate description of these substances useful for health. However, due to the limited ability to reproduce the conditions prevailing in the human gastrointestinal tract, the knowledge about the action of these compounds and their metabolism both individually and in interaction with other food components should still be complemented by indirect tests involving experimental animals as well as the direct ones using volunteers involvement.

\section{REFERENCES}

Acosta-Estrada, B.A., Gutiérrez-Uribe, J.A., Serna-Saldívar, S.O. 2014. Bound phenolics in foods, a review. Food Chem, 152(1), 46-55.

Andersson, A.A.M., Dimberg, L., Åman, P., Landberg, R. 2014. Recent findings on certain bioactive components in whole grain wheat and rye. J Cereal Sci, 59(3), 294-311.

Andreasen, M.F., Christensen, L.P., Meyer, A.S., Hansen, A. 2000. Content of phenolic acids and ferulic acid dehydrodimers in 17 rye (Secale cereale L.) varieties. J Agr Food Chem, 48(7), 2837-2842.

Andreasen, M.F., Kroon, P.A., Williamson, G., Garcia-Conesa, M.T. 2001a. Esterase activity able to hydrolyze dietary antioxidant hydroxycinnamates is distributed along the intestine of mammals. J Agr Food Chem, 49(11), 5679-5684.

Andreasen, M.F., Kroon, P.A., Williamson, G., Garcia-Conesa, M.T. 2001b. Intestinal release and uptake of phenolic antioxidant diferulic acids. Free Radical Bio Med, 31(3), 304-314. 
Biely, P., Singh, S., Puchart, V. 2016. Towards enzymatic breakdown of complex plant xylan structures: State of the art. Biotechnol Adv, 34(7), 1260-1274.

Bondia-Pons, I., Aura, A.-M., Vuorela, S., Kolehmainen, M., Mykkänen, H., Poutanen, K. 2009. Rye phenolics in nutrition and health. J Cereal Sci, 49(3), 323-336.

Brand-Williams, W., Cuvelier, M.E., Berset, C., 1995. Use of a free radical method to evaluate antioxidant activity. LWT - Food Sci Technol, 28(1), 25-30.

Budryn, G., Nebesny, E. 2006. Fenolokwasy - ich właściwości, występowanie w surowcach roślinnych, wchłanianie i przemiany metaboliczne. Bromatol Chem Toksyk, 39(2), 103-110.

Bunzel, M., Ralph, J., Marita, J.M., Hatfield, R.D., Steinhart, H. 2001. Diferulates as structural components in soluble and insoluble cereal dietary fibre. J Sci Food Agr, 81(7), 653-660.

Bushuk, W., 2001. Rye: production, chemistry, and technology, 2 edition. ed. Amer Assn of Cereal Chemists, St. Paul, Minn.

Cacak-Pietrzak, G. 2016. Wykorzystanie ziarna żyta na cele konsumpcyjne i inne. Presented at the Kontrola jakosci w obrocie i przetworstwie ziarna zboz, Krynica Morska, pp. 18-19.

Chen, Y., Ross, A.B., Åman, P., Kamal-Eldin, A. 2004. Alkylresorcinols as markers of whole grain wheat and rye in cereal products. J Agr Food Chem, 52(26), 8242-8246.

Chesson, A., Provan, G.J., Russell, W.R., Scobbie, L., Richardson, A.J., Stewart, C. 1999. Hydroxycinnamic acids in the digestive tract of livestock and humans. J Sci Food Agr, 79(3), 373-378.

Cheynier, V., Comte, G., Davies, K.M., Lattanzio, V., Martens, S. 2013. Plant phenolics: Recent advances on their biosynthesis, genetics, and ecophysiology. Plant Physiol Bioch, 72, 1-20.

Curiel, J.A., Rodríguez, H., Landete, J.M., de las Rivas, B., Muñoz, R. 2010. Ability of Lactobacillus brevis strains to degrade food phenolic acids. Food Chem,120(1), 225-229.

Dedio, W., Hill, R.D., Evans, L.E. 1972. Anthocyanins in the pericarp and coleoptiles of purple-seeded rye. Can J Plant Sci, 52(6), 981-983.

Dimberg, L.H., Moltenberg, E.L., Solheim, R., Frolich, W. 1996. Variation in oat groats due to variety, storage and heat treatment. I: Phenolic compounds. J Cereal Sci, 24(3), 263-272.

During, A., Debouche, C., Raas, T., Larondelle, Y. 2012. Among plant lignans, pinoresinol has the strongest antiinflammatory properties in human intestinal Caco-2 cells. J Nutr, 142(10), 1798-1805.

Dykes, L., Rooney, L.W. 2007. Phenolic compounds in cereal grains and their health benefits. Cereal Foods Worlds, 105-111.

Dynkowska, W.M., Cyran, M.R., Ceglińska, A. 2015. Soluble and cell wall-bound phenolic acids and ferulic acid dehydrodimers in rye flour and five bread model system: Insight into mechanisms of improved availability. J Sci Food Agr, 95(5), 1103-1115.

FAOSTAT http://www.fao.org/faostat/en/\#home

Fazary, A.E., Ju, Y.-H. 2007. Feruloyl esterases as biotechnological tools: current and future perspectives. Acta Bioch Bioph Sin, 39(11), 811-828.

Figueroa-Espinoza, M.C., Rouau, X. 1998. Oxidative cross-linking of pentosans by a fungal laccase and horseradish peroxidase: mechanism of linkage between feruloylated arabinoxylans. Cereal Chem, 75(2), $259-265$

Gänzle, M.G. 2014. Enzymatic and bacterial conversions during sourdough fermentation. Food Microbiol, 37 , 2-10.

Geissman, T., Neukom, H. 1973. A note of ferulic acid as a constituent of the water-insoluble pentosans of wheat flour. Cereal Chem, 50, 414-416.

Glitsø, L.V., Bach Knudsen, K.E. 1999. Milling of whole grain rye to obtain fractions with different dietary fibre characteristics. J Cereal Sci, 29(1), 89-97.

Gulçin, İ. 2012. Antioxidant activity of food constituents: an overview. Arch Toxicol, 86(3), 345-391.

Hansen, H.B., Rasmussen, C.V., Knudsen, K.E.B., Hansen, Å. 2003. Effects of genotype and harvest year on content and composition of dietaty fibre in rye (Secale cereale L.) grain. J Sci Food Agr, 83(1), 76-85.

Hatfield, R.D., Rancour, D.M., Marita, J.M. 2017. Grass cell walls: A story of cross-linking. Front Plant Sci 7, 2056.

Heim, K.E., Tagliaferro, A.R., Bobilya, D.J. 2002. Flavonoid antioxidants: Chem, metabolism and structureactivity relationships. $J$ Nutr Biochem, 13(10), 572-584.

Heiniö, R.-L., Liukkonen, K.-H., Katina, K., Myllymäki, O., Poutanen, K. 2003. Milling fractionation of rye produces different sensory profiles of both flour and bread. LWT - Food Sci Technol, 36(6), 577-583.

Heiniö, R.-L., Liukkonen, K.-H., Myllymäki, O., Pihlava, J.-M., Adlercreutz, H., Heinonen, S.-M., Poutanen, K. 2008. Quantities of phenolic compounds and their impacts on the perceived flavour attributes of rye grain. J Cereal Sci, 47(3), 566-575.

Huang, D., Ou, B., Prior, R.L. 2005. The chemistry behind antioxidant aapacity assays. J Agr Food Chem, 53 (6), 1841-1856.

Iiyama, K., Lam, T.B.T., Stone, B.A. 1994. Covalent cross-links in the cell wall. Plant Physiol, 104(2), 315320.

Izydorczyk, M.S., Biliaderis, C.G. 1995. Cereal arabinoxylans: advances in structure and physicochemical properties. Carbohyd Polym, 28(1), 33-48.

Kamal-Eldin, A., Appelqvist, L.A. 1996. The chemistry and antioxidant properties of tocopherols and tocotrienols. Lipids, 31(7), 671-701. 
Katina, K., Heiniö, R.-L.,Autio, K., Poutanen, K. 2006. Optimization of sourdough process for improved sensory profile and texture of wheat bread. LWT - Food Sci Technol, 39(10), 1189-1202.

Katina, K., Liukkonen, K.-H., Kaukovirta-Norja, A., Adlercreutz, H., Heinonen, S.-M., Lampi, A.-M., Pihlava, J.-M., Poutanen, K. 2007. Fermentation-induced changes in the nutritional value of native or germinated rye. J Cereal Sci, 46(3), 348-355.

Kołodziejczyk-Czepas, J., Szejk, M., Pawlak, A., Żbikowska, H.M. 2015. Właściwości przeciwutleniające kwasu kawowego i jego pochodnych. Żywn-Nauk Technol Ja, 3(100), 5-17.

Kroon, P.A., Williamson, G. 1999. Hydroxycinnamates in plants and food: current and future perspectives. $J$ Sci Food Agr, 79(3), 355-361.

Kroon, P., Garcia-Conesa, M., Fillingham, I., Hazlewood, G., Williamson, G. 1999. Release of ferulic acid dehydrodimers from plant cell walls by feruloyl esterases. J Sci Food Agr, 79(3), 428-434.

Kulawinek, M., Jaromin, A., Kozubek, A., Zarnowski, R. 2008. Alkylresorcinols in selected Polish rye and wheat cereals and whole-grain cereal products. J Agr Food Chem, 56(16), 7236-7242.

Lam, T.B.T., Kadoya, K., Iiyama, K. 2001. Bonding of hydroxycinnamic acids to lignin: ferulic and pcoumaric acids are predominantly linked at the benzyl position of lignin, not the $\beta$-position, in grass cell walls. Phytochemistry, 57(6), 987-992.

Maeda, H., Dudareva, N., 2012. The shikimate pathway and aromatic amino acid biosynthesis in plants. Annu Rev Plant Biol, 63, 73-105.

Mancuso, C., Santangelo, R. 2014. Ferulic acid: pharmacological and toxicological aspects. Food Chem Toxicol, 65, 185-195.

Masuda, T., Yamada, K, Akiyama, J., Someya, T., Odaka, Y, Takeda, Y., Tori, M., Nakashima, K, Maekawa, T., Sone, Y. 2008. Antioxidation mechanism studies of caffeic acid: identification of antioxidation products of methyl caffeate from lipid oxidation. J Agr Food Chem, 56(14), 5947-5952.

Mathew, S., Abraham, T.E. 2004. Ferulic acid: an antioxidant found naturally in plant cell walls and feruloyl esterases involved in its release and their applications. Crit Rev Biotechnol, 24(2-3), 59-83.

Mathew, S., Abraham, T.E. 2006. Bioconversions of ferulic acid, an hydroxycinnamic acid. Crit Rev Microbiol, 32(3), 115-125

Meents, M.J., Watanabe, Y., Samuels, A.L. 2018. The cell biology of secondary cell wall biosynthesis. Ann Bot, 121(6), 1107-1125.

Micard, V., Landazuri, T., Surget, A., Moukha, S., Labat, M., Rouau, X. 2002. Demethylation of ferulic acid and feruloyl arabinoxylan by microbial cel extracts. LWT - Food Sci Technol, 35(3), 272-276.

Michalska, A., Ceglinska, A., Amarowicz, R., Piskula, M.K., Szawara-Nowak, D., Zielinski, H. 2007a. Antioxidant contents and antioxidative properties of traditional rye breads. J Agr Food Chem, 55(3), 734740 .

Michalska, A., Ceglińska, A., Zieliński, H. 2007b. Bioactive compounds in rye flours with different extraction rates. Eur Food Res Technol, 225(3-4), 545-551.

Moltenberg, E.L., Solheim, Dimberg, L.H., R., Frolich, W. 1996. Variation in oat groats due to variety, storage and heat treatment. II: Sensory quality. J Cereal Sci, 24(3), 273-282.

Moon, J.-K., Shibamoto, T. 2009. Antioxidant assays for plant and food components. J Agr Food Chem, 57 (5), 1655-1666

Moore, A.M., Martinez-Munoz, I., Hoseney, R.C. 1990. Factors affecting the oxidative gelation of wheat water-solubles'. Cereal Chem, 67(1), 81-84.

Naczk, M., Shahidi, F. 2004. Extraction and analysis of phenolics in food. J Chromatogr A, 1054(1-2), 95111.

Natella, F., Nardini, M., Di Felice, M., Scaccini, C., 1999. Benzoic and cinnamic acid derivatives as antioxidants: structure-activity relation. J Agr Food Chem, 47(4), 1453-1459.

Nimse, S.B., Pal, D. 2015. Free radicals, natural antioxidants, and their reaction mechanisms. RSC Adv, 5, 27986-28006.

Nyström, L., Lampi, A.-M., Andersson, A.A.M., Kamal-Eldin, A., Gebruers, K, Courtin, C.M., Delcour, J.A Li, L., Ward, J.L., Fraś, A., Boros, D., Rakszegi, M., Bedő, Z., Shewry, P.R., Piironen, V. 2008. Phytochemicals and Dietary Fiber Components in Rye Varieties in the HEALTHGRAIN Diversity Screen. $J$ Agr Food Chem, 56(21), 9758-9766.

Ou, S., Kwok, K.-C. 2004. Ferulic acid: pharmaceutical functions, preparation and applications in foods. $J$ Sci Food Agr, 84(11), 1261-1269.

Pihlava, J.-M., Nordlund, E., Heiniö, R.-L., Hietaniemi, V., Lehtinen, P., Poutanen, K. 2015. Phenolic compounds in wholegrain rye and its fractions. J Food Compos Anal, 38, 89-97.

Pihlava, J.-M., Hellström, J., Kurtelius, T., Mattila, P. 2018. Flavonoids, anthocyanins, phenolamides, benzoxazinoids, lignans and alkylresorcinols in rye (Secale cereale L.) and some rye products. J Cereal Sci, 79 (1), 183-192.

Piironen, V., Sylväoja, E.-L., Varo, P., Salminen, K., Koivistoinen, P. (1986). Tocopherols and tocotrienols in cereal products rom Finland. Cereal Chem, 63(2), 78-81.

Pisoschi, A.M., Pop, A. 2015. The role of antioxidants in the chemistry of oxidative stress: A review. Eur J Med Chem, 97, 55-74.

Poutanen, K., Flander, L., Katina, K. 2009. Sourdough and cereal fermentation in a nutritional perspective. Food Microbiol, 26(7), 693-699. 
Poutanen, K., Åman, P. (eds.) 2014. Rye and Health, 1st ed. AACC International.

Prior, R.L., Wu, X., Schaich, K. 2005. Standardized methods for the determination of antioxidant capacity and phenolics in foods and dietary supplements. J Agr Food Chem, 53(10), 4290-4302.

Quideau, S., Deffieux, D., Douat-Casassus, C., Pouységu, L. 2011. Plant polyphenols: chemical properties, biological activities, and synthesis. Angew Chem Int Ed Engl, 50, 586-621.

Ragaee, S.M., Campbell, G.L., Scoles, G.J., McLeod, J.G., Tyler, R.T. 2001. Studies on rye (Secale cereal L.) lines exhibiting a range of extracts viscosities. 1. Composition, molecular weight distribution of water extract, and biochemical characteristics of purified water-extractable arabinoxylan. J Agric Food Chem, 49(5), 2437-2445.

Ragaee, S.M., Abdel-Aal, E., Noaman, M. 2006. Antioxidant activity and nutrient composition of selected cereals for food use. Food Chem, 98(1), 32-38.

Ralph, J., Quideau, S., Grabber, J.H., Hatfield, R.D. 1994. Identification and synthesis of new ferulic acid dehydrodimers present in grass cell walls. J Chem Soc Perkin 1, 23, 3485-3498.

Re, R., Pellegrini, N., Proteggente, A., Pannala, A., Yang, M., Rice-Evans, C. 1999. Antioxidant activity applying an improved ABTS radical cation decolorization assay. Free Radical Bio Med, 26(9-10), 1231-1237.

Rice-Evans, C.A., Miller, N.J., Paganga, G. 1996. Structure-antioxidant activity relationships of flavonoids and phenolic acids. Free Radical Bio Med, 20(7), 933-956.

Rice-Evans, C., Miller, N., Paganga, G. 1997. Antioxidant properties of phenolic compounds. Trends Plant Sci 2(4), 152-159.

Statistical Yearbook 2017. Główny Urząd Statystyczny, Rozkrut, D. (ed.) Zakład Wydawnictw Statystycznych, Warszawa. pp. 495.

Rodríguez, H., Curiel, J.A., Landete, J.M., de las Rivas, B., de Felipe, F.L., Gómez-Cordovés, C., Mancheño, J.M., Muñoz, R. 2009. Food phenolics and lactic acid bacteria. International J Food Microb, 132(2-3), 79-90.

Rothwell, J.A., Urpi-Sarda, M., Boto-Ordoñez, M., Llorach, R., Farran-Codina, A., Barupal, D.K., Neveu, V., Manach, C., Andres-Lacueva, C., Scalbert, A. 2016. Systematic analysis of the polyphenol metabolome using the Phenol-Explorer database. Mol Nutr Food Res, 60(1), 203-211.

Saulnier, L., Thibault, J.F. 1999. Ferulic acid and diferulic acids as components of sugar-beet pectins and maize bran heteroxylans. J Sci Food Agr, 79(3), 396-402.

Selma, M.V., Espín, J.C., Tomás-Barberán, F.A. 2009. Interaction between phenolics and gut microbiota: role in human health. J Agr Food Chem, 57(15), 6485-6501.

Shahidi, F., Yeo, J.-D. 2016. Insoluble-bound phenolics in food. Molecules, 21(9), https://doi.org/10.3390/ molecules21091216.

Slavin, J.L. 2000. Mechanisms for the impact of whole grain foods on cancer risk. J Am Coll Nutr, 19(3 Suppl), 300S-307S

Sroka, Z., Cisowski, W. 2003. Hydrogen peroxide scavenging, antioxidant and anti-radical activity of some phenolic acids. Food Chem Toxicol, 41(6), 753-758.

Suzuki, Y., Esumi, Y., Uramoto, M., Kono, Y., Sakurai, A. 1997. Structural analyses of carbon chains in 5-alk (en)ylresorcinols of rye and wheat whole flour by tandem mass spectrometry. BioSci Biotech Bioch, 61 (3), 480-486.

Suzuki, Y., Esumi, Y., Yamaguchi, I. 1999. Structures of 5-alkylresorcinol-related analogues in rye. Phytochemistry, 52(2), 281-289.

Tzin, V., Galili, G. 2010. New insights into the shikimate and aromatic amino acids biosynthesis pathways in plants. Mol Plant, 3(6), 956-972.

van Beek, S., Priest, F.G. 2000. Decarboxylation of substituted cinnamic acids by lactic acid bacteria isolated during malt whisky fermentation. Appl Environ Microbiol, 66(12), 5322-5328.

Vinkx, C.J.A. Nieuwenhove, C.G. van, Delcour, J.A. 1991. Physicochemical and functional properties of rye nonstarch polysaccharides. III. Oxidative gelation of a fraction containing water-soluble pentosans and proteins. Cereal Chem, 68(6), 617-622.

Virtanen, A.I., Hietala, P.K. 1955. 2(3)-Benzoxazolinone, an anti-fusarium factior in rye seedlings. Acta Chem Scand, 9, 1543-1544.

Viskupičová, J., Ondrejovič, M., Šturdík, E. 2008. Bioavailability and metabolism of flavonoids. J Food Nutr Res, 47(4), 151-162.

Weaver, L.M., Herrmann, K.M. 1997. Dynamics of the shikimate pathway in plants. Trends Plant Sci, 2(9), 346-351.

Williams, R.J., Spencer, J.P.E., Rice-Evans, C. 2004. Flavonoids: antioxidants or signalling molecules? Free Radical Bio Med, 36(7), 838-849.

Williamson, G., Day, A.J., Plumb, G.W., Couteau, D. 2000. Human metabolic pathways of dietary flavonoids and cinnamates. Biochem $\operatorname{Soc} T, 28(2), 16-22$

Wong, K.K., Tan, L.U., Saddler, J.N. 1988. Multiplicity of beta-1,4-xylanase in microorganisms: functions and applications. Microbiol Rev, 52(3), 305-317.

Zhao, Z., Moghadasian, M.H. 2008. Chemistry, natural sources, dietary intake and pharmacokinetic properties of ferulic acid: A review. Food Chem, 109(4), 691-702.

Zieliński, H., Ceglińska, A., Michalska, A. 2007. Antioxidant contents and properties as quality indices of rye cultivars. Food Chem, 104(3), 980-988. 